\title{
A marker tephra bed close to the Lower-Middle Pleistocene boundary: Distribution of the Ontake-Byakubi Tephra Bed in central Japan
}

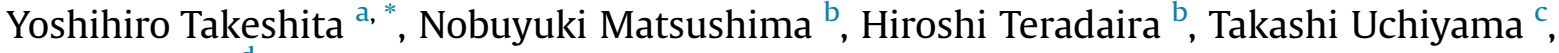 \\ Hisao Kumai ${ }^{\mathrm{d}}$ \\ a Institute of Education, Shinshu University, 6-ro, Nishinagano, Nagano 380-8544, Japan \\ ${ }^{\mathrm{b}}$ Nature Association of Ina Valley, 2-655-7, Ottemachi, Iida, Nagano 395-0034, Japan \\ ${ }^{\mathrm{c}}$ Mount Fuji Research Institute, Yamanashi Prefectural Government, 5597-1 Kenmarubi, Kamiyoshida, Fujiyoshida, Yamanashi 403-0005, Japan \\ d Osaka City University, 3-3-138 Sugimoto, Sumiyoshi, Osaka 558-8585, Japan
}

\section{A R T I C L E I N F O}

\section{Article history:}

Available online $\mathrm{xxx}$

\section{Keywords:}

Lower-Middle Pleistocene boundary

Older Ontake volcano

Ontake-Byakubi Tephra Bed

Correlation

Hornblende

Major element composition

\begin{abstract}
A B S T R A C T
Tephrochronology is an exceptionally important tool in the precise regional correlation of Early and Middle Pleistocene sedimentary strata in Japan. The present study reveals that the Yukawa tephra 5 (YUT5) derived from the Older Ontake volcano, the Nezumigawa (Nzg) and Mitamitajima (Mtj) tephras of the Ina Bazin, and the Byakubi-E tephra (Byk-E) of the Boso Peninsula are the same tephra on the basis of their lithofacies, bulk grain composition, mafic mineral composition, major element composition of hornblende, and stratigraphic relationships with the dated tephras. We propose to call the series of tephras correlated with Byk-E the Ontake-Byakubi Tephra Bed (On-Byk Tephra) following the naming convention in which the tephra name consists of the names of the source volcano and the type location. The Matuyama-Brunhes Chronozone boundary occurs just above Byk-E in the type section of the Kokumoto Formation in the Kazusa Group, which is a candidate Global Boundary Stratotype Section and Point (GSSP) for the lower boundary of the Middle Pleistocene Subseries. Therefore, On-Byk Tephra becomes a critically important marker tephra bed for the Early-Middle Pleistocene boundary in central Japan. The present study indicates that the major element composition of hornblende can be a useful tool for identification and correlation of strongly weathered tephra layers such as Nzg and Mtj in which all the volcanic glass shards have been altered.
\end{abstract}

() 2015 Elsevier Ltd and INQUA. All rights reserved.

\section{Introduction}

The Kazusa Group, which is widely distributed in the central part of the Boso Peninsula, is representative of Lower and Middle Pleistocene marine sediments in Japan. Comprehensive studies of the lithostratigraphy, biostratigraphy, magnetostratigraphy, and oxygen-isotope stratigraphy of this group have been carried out (Working Group for Quaternary Stratigraphy of Boso, 2009; Kazaoka et al., 2015). A continuous exposure of the Kokumoto Formation, middle part of the Kazusa Group, along the Yoro River, Chiba Prefecture, is a candidate Global Boundary Stratotype Section and Point (GSSP) for the lower boundary of the Middle Pleistocene Subseries (Head et al., 2008). The Kazusa Group contains numerous tephra layers, and the tephrostratigraphy is well constrained by

\footnotetext{
* Corresponding author.

E-mail address: takey@shinshu-u.ac.jp (Y. Takeshita).
}

many marker tephras (Mitsunashi et al., 1959, 1979; Satoguchi, 1995, 1996; Satoguchi and Nagahashi, 2012). Among the tephra layers, the Byakubi-E tephra (Byk-E: Kazaoka et al., 2015) in the middle part of the Kokumoto Formation, is intercalated approximately $1 \mathrm{~m}$ below the Matuyama-Brunhes Polarity Chronozone boundary (Kazaoka et al., 2015). Therefore, Byk-E has the potential to be an important regional marker tephra bed for the LowerMiddle Pleistocene boundary if its distributional area and characteristics for identification and correlation are clarified.

Takeshita et al. (2005) showed that Byk-E is correlated with either the Yukawa tephra 4 or 5 (YUT4 or YUT5) at the foot of Ontake volcano in central Japan, and showed that its source was the Older Ontake volcano. Byk-E has not been correlated, however, with tephra layers in any other locality. In this paper, we show that the Minamitajima (Mtj) and Nezumigawa (Nzg) tephras in the Ina basin, which lies between the Boso Peninsula and the Older Ontake volcano, correlate with Byk-E. This correlation confirms that Byk-E was erupted from the Older Ontake volcano. Furthermore, we show 


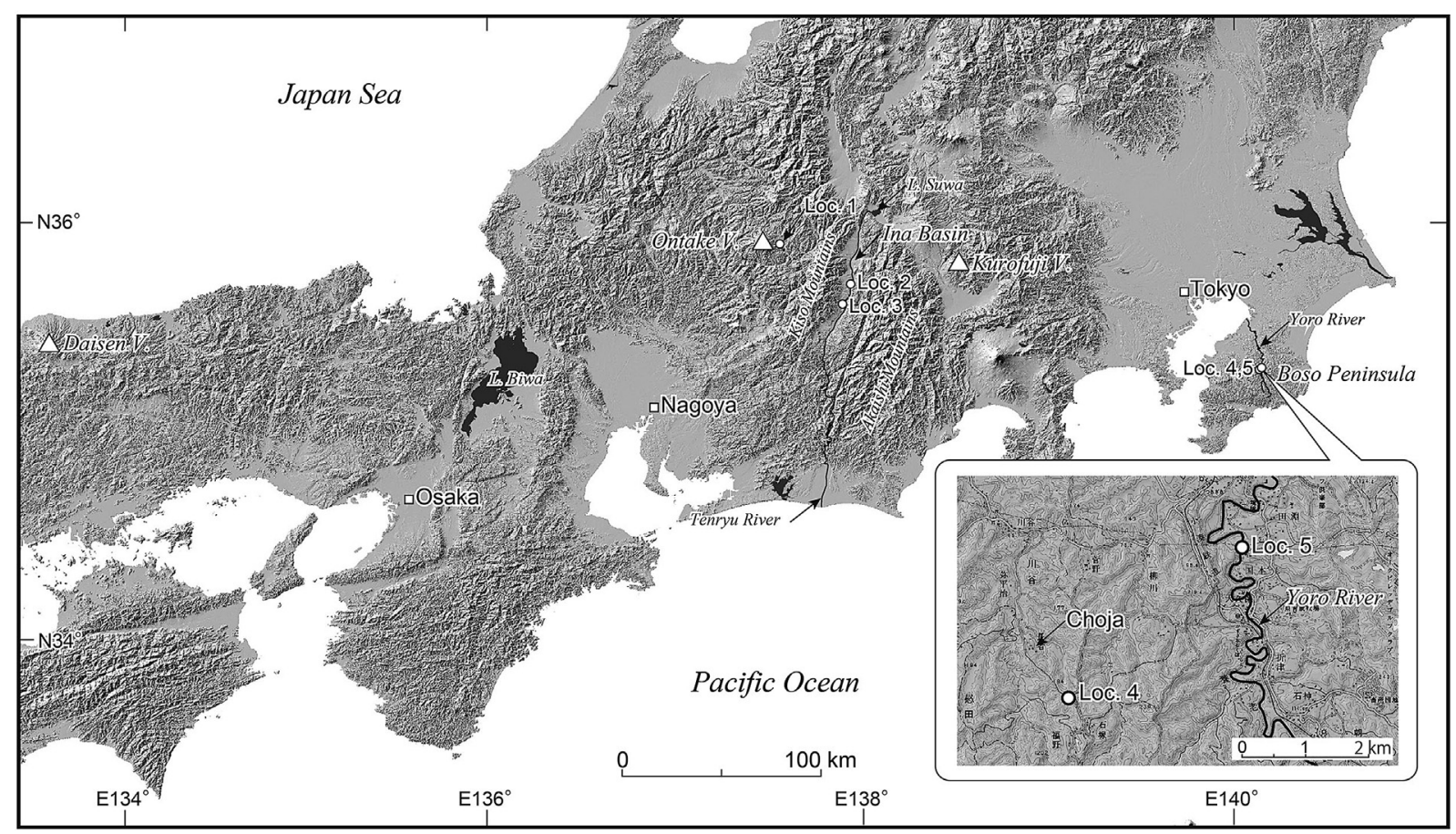

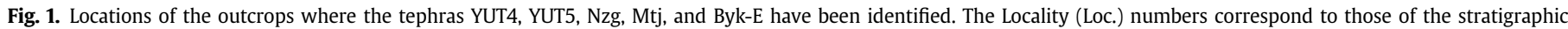
columns shown in Fig. 3. The relief map was produced by Kashmir 3D using the $50 \mathrm{~m}$ mesh DEM data published by the Geospatial information Authority of Japan.

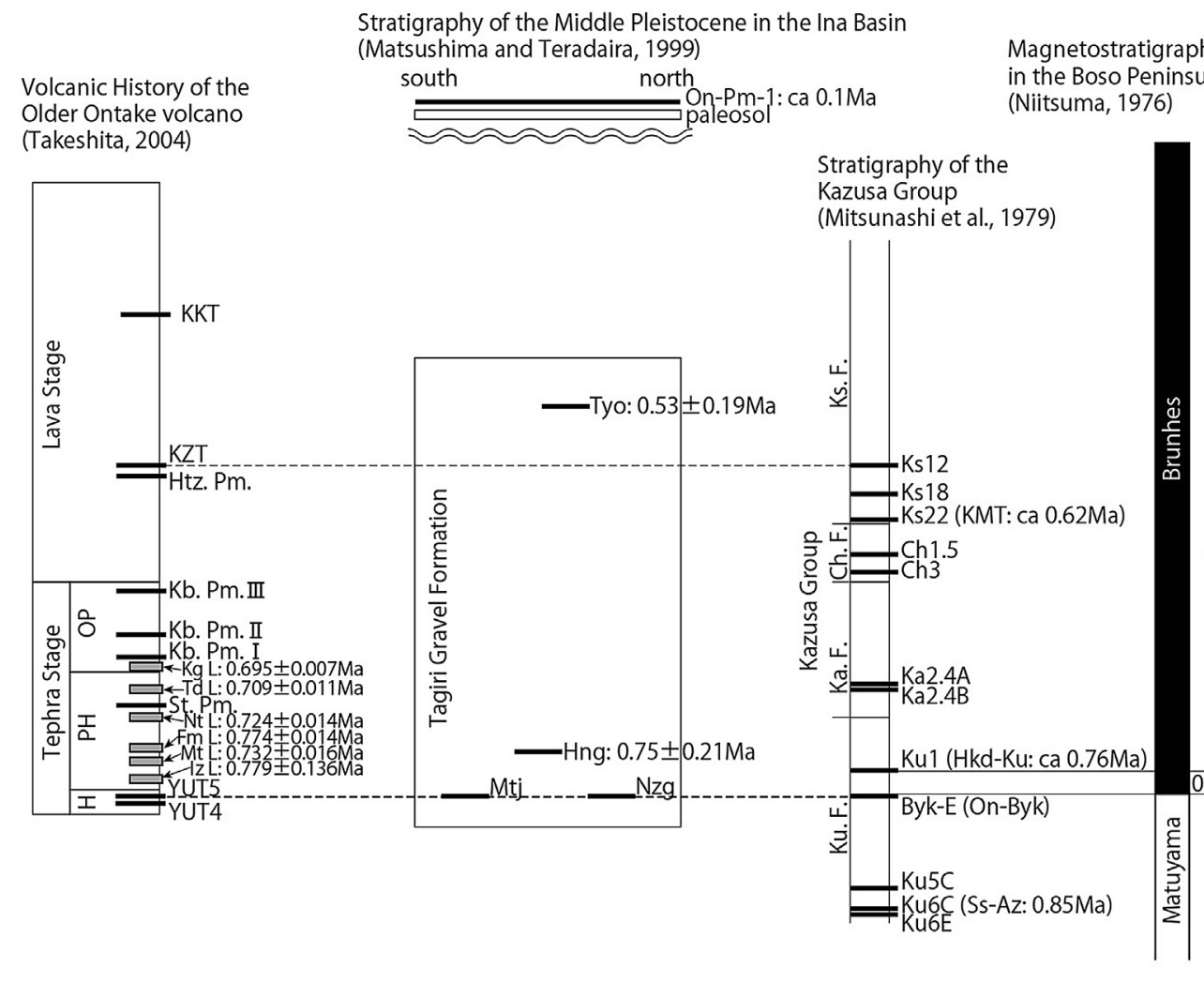

Stratigraphy of the Middle Pleistocene in the Ina Basin
(Matsushima and Teradaira, 1999)

ratigraphy of the

(Mitsunashi et al., 1979)
Planktic $\delta$ O-\% (Pickering et al., 1994)

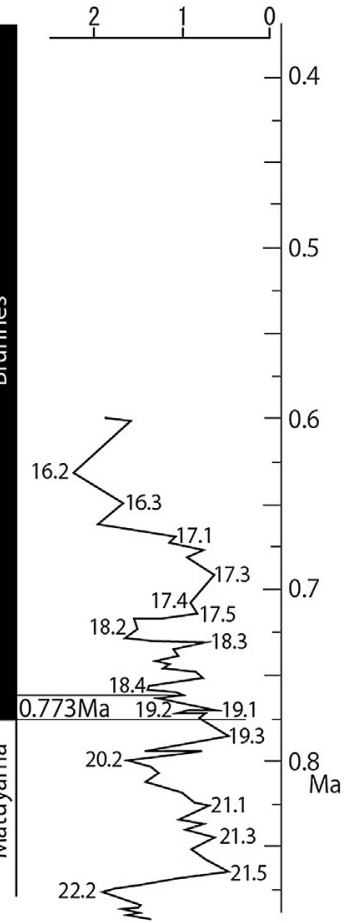

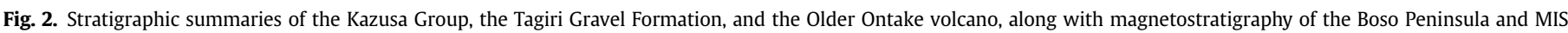

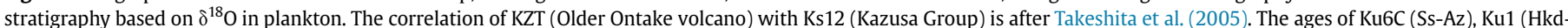

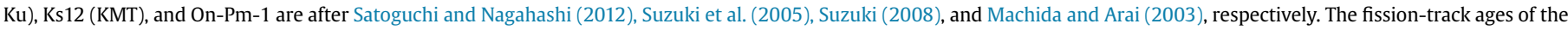

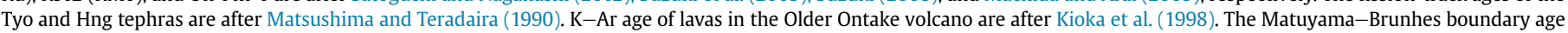

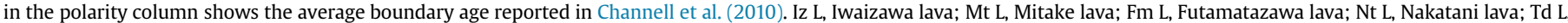

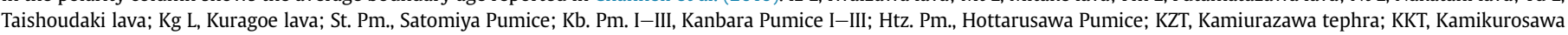
tephra; H, Substage H; PH, Substage PH; OP, Substage OP; Ku, Kokumoto; Ka, Kakinokidai; Ch, Chonan; Ks, Kasamori; F, Formation. 
that Byk-E is correlated with YUT5, not YUT4. Here, we propose to call the series of tephras that correlate with Byk-E the OntakeByakubi tephra (On-Byk).

\section{Geological settings of the tephras}

\subsection{Yukawa tephra 4 (YUT4) and Yukawa tephra 5 (YUT5), tephra} beds of the Older Ontake volcano

Ontake volcano, which is an active volcano is situated at the southern margin of the Norikura volcanic chain, central Japan (Fig. 1), consists of Older and Younger Ontake volcanoes (Yamada and Kobayashi, 1988). The Older Ontake volcano is estimated to have been active about $0.78-0.39 \mathrm{Ma}$, based on $\mathrm{K}-\mathrm{Ar}$ ages of 47 lavas (Kioka et al., 1998). Younger Ontake volcano became active about $0.1 \mathrm{Ma}$ and was the source of a phreatic eruption in 1979 and 2014 (Oikawa, 2014). The products of Younger Ontake volcano constitute the main part of the edifice of Ontake volcano (Kimura, 1993), whereas the products of Older Ontake volcano are widely distributed around the foot of the volcano (Matsumoto Basin Collaborative Research Group, 2002).

The activity of Older Ontake Volcano has been divided into a Tephra Stage (about 0.78-0.64 Ma) and a Lava Stage (0.64-0.39 Ma), based on the primary mode of eruption. The Tephra Stage was characterized by the eruption of many airfall tephras and pyroclastic flows, whereas the Lava Stage produced many thick lavas (Fig. 2). The Satomiya Pumice, Kambara Pumices I, II, and III (Tephra Stage), and the Hottaruzawa Pumice (Lava Stage) are key tephra layers that have been widely traced at the foot area of the volcano (Matsumoto Basin Collaborative Research Group, 2002). The Tephra Stage has been further subdivided on the basis of the dominant mafic minerals into substages $\mathrm{H}$ (ca. $0.78 \mathrm{Ma}$ ), $\mathrm{PH}$ $(0.78-0.70 \mathrm{Ma})$, and $\mathrm{OP}(0.70-0.64 \mathrm{Ma})$, where $\mathrm{H}$ stands for hornblende, $\mathrm{PH}$ for pyroxenes and hornblende, and OP for olivine and pyroxenes (Takeshita, 2004). YUT4 and YUT5 belong to Substage $\mathrm{H}$, and the Kamiurazawa tephra (KZT), which belongs to the Lava Stage, has been correlated with the Ks12 tephra (Takeshita et al., 2005), which is in the Kasamori Formation of the Kazusa Group.

The Yukawa tephras 1-5 (YUT1-5) are Substage $H$ tephras (Takeshita, 2004), and their type locality is along the Yukawa River at the foot of the eastern slope of Older Ontake volcano (Locality 1; N35 $54^{\prime} 15^{\prime \prime}$, E137 $34^{\prime} 03^{\prime \prime}, 1200$ m a.s.l.; Fig. 1). YUT4 consists of a gray volcanic ash bed (36 cm thick) overlain by sorted white pumice fall deposits ( $46 \mathrm{~cm}$ thick) (Fig. 3). The upper part of YUT4 consists mainly of pumice grains up to $1.0-2.5 \mathrm{~cm}$ in diameter. YUT5 consists of sorted white pumice fall deposits, $53 \mathrm{~cm}$ thick, containing pumice grains as large as $1.0-2.0 \mathrm{~cm}$ in diameter. YUT4 and 5 overlies the slope of approximately $20^{\circ}$, which show mantle bedding (Fig. 4). A gravel bed (about $160 \mathrm{~cm}$ thick) lies between YUT4 and 5. Samples of YUT4 and YUT5 collected at Locality 1 (Takeshita, 2004) were used in this study.
Ina Basin

Boso Peninsula

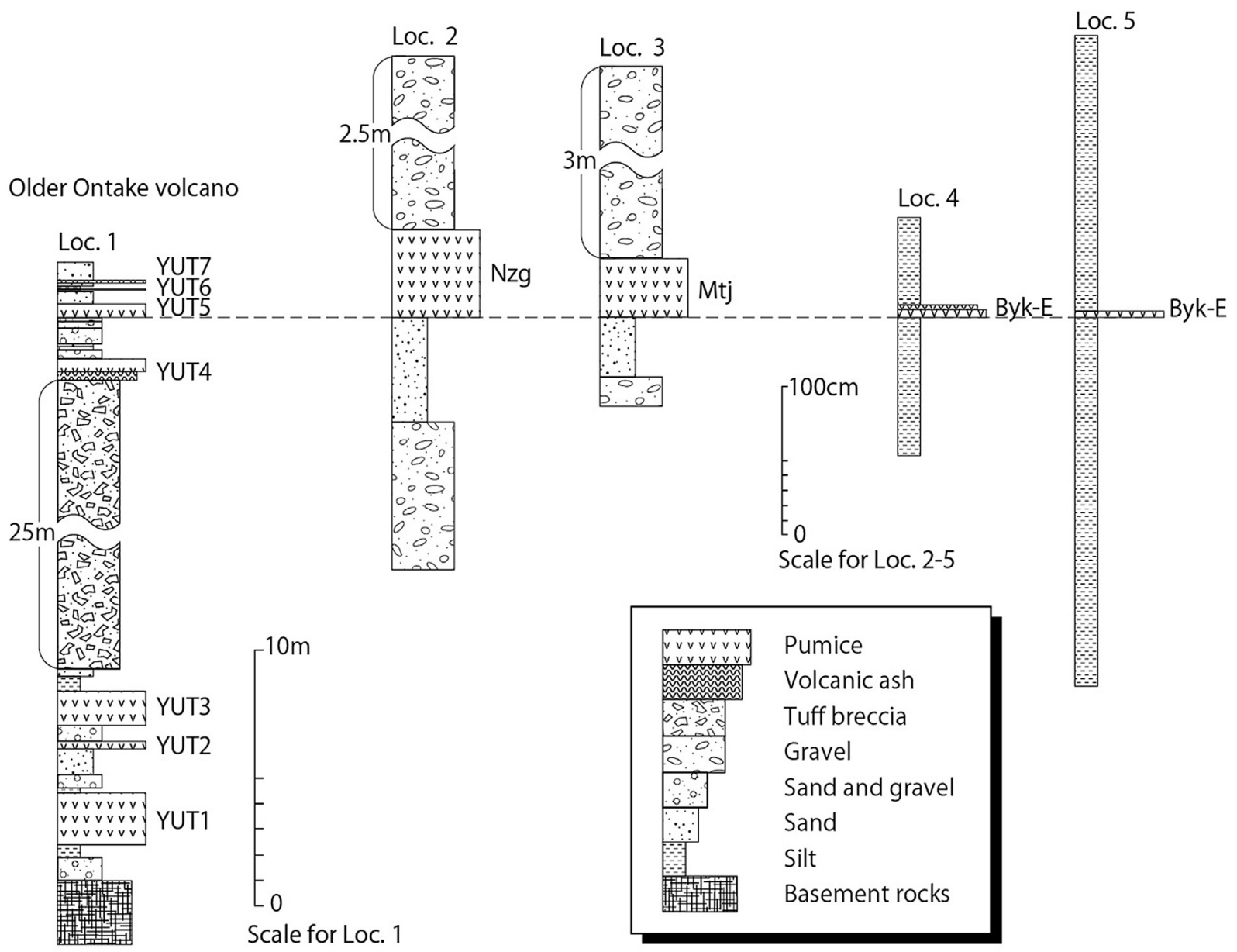

Fig. 3. Stratigraphic columns of Location 1 to Location 5 showing the relationships among YUT4, YUT5, Nzg, Mtj, and Byk-E tephra beds. The locations are shown in Fig. 1. 


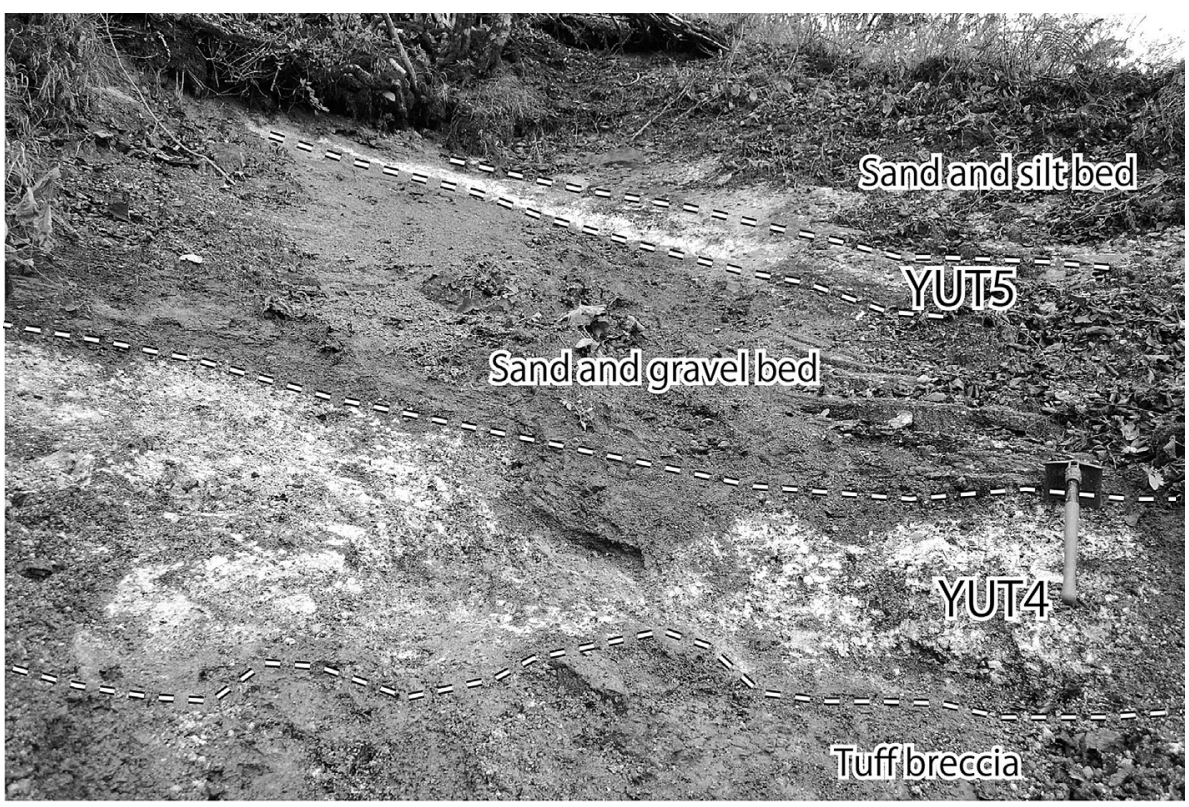

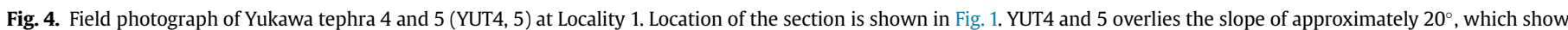
mantle bedding.

\subsection{Minamitajima (Mtj) and Nezumigawa (Nzg) tephras and the Tagiri Gravel Formation in the Ina basin}

The Ina basin, $50 \mathrm{~km}$ east of Ontake volcano, is an elongated basin approximately $60 \mathrm{~km}$ long (north-south) and $15 \mathrm{~km}$ wide

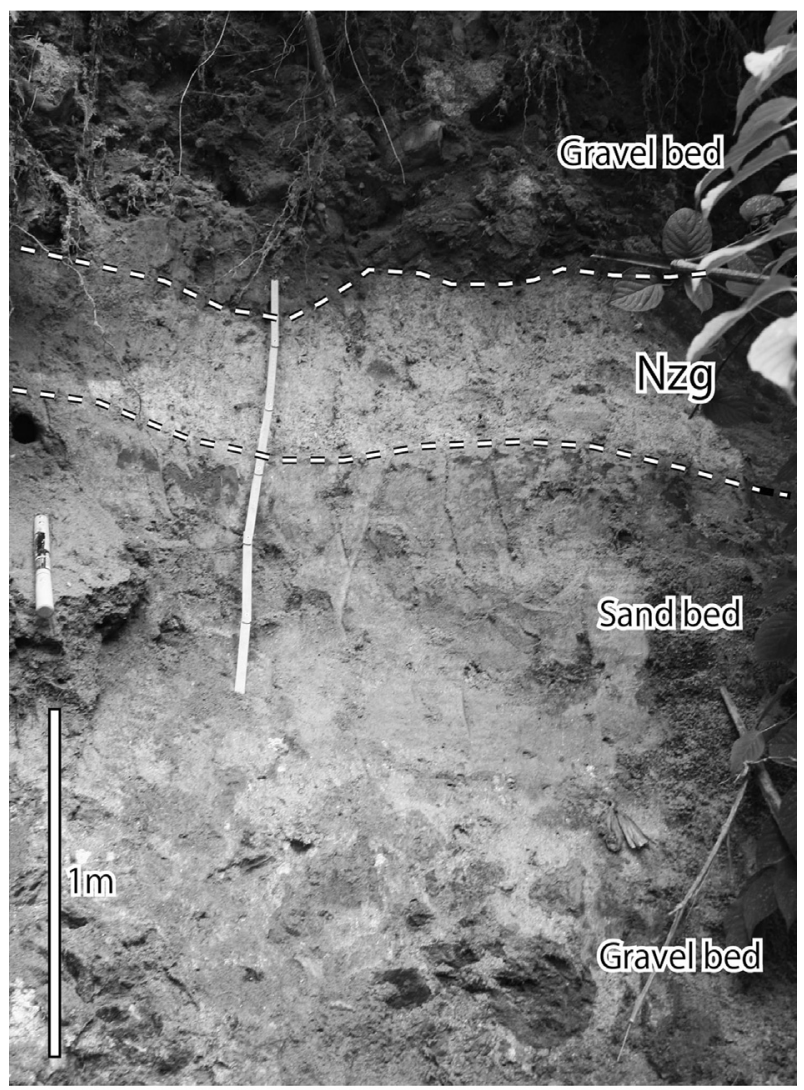

Fig. 5. Field photograph of Nezumigawa tephra (Nzg) at Locality 2. Location of the section is shown in Fig. 1. (east-west) (Fig. 1). It is bounded on the east by the Akaishi Mountains and on the west by the Kiso Mountains. The Tenryu River flows out of Lake Suwa and down the eastern side of the basin. The Middle Pleistocene Tagiri Gravel Formation occurs in the basin west of the Tenryu River (Matsushima, 1995). The Tagiri Gravel Formation is overlain by paleosol $1.0-1.5 \mathrm{~m}$ thick and the Ontake Pm-1 tephra (On-Pm-1, 0.1 Ma; Kobayashi et al., 1967; Machida and Arai, 2003) (Fig. 2). The composition of the gravel, which consists of rocks found in the Kiso Mountains, suggests that this formation was deposited during the uplift of the Kiso Mountains (Matsushima, 1995). Tephras interbedded in the Tagiri gravel include the Minamitajima (Mtj) (Matsushima and Teradaira, 1999), Nezumigawa (Nzg) (Matsushima et al., 2007), Hongo (Hng) and Toyooka (Tyo) tephras (Matsushima and Teradaira, 1990) (Fig. 2). The stratigraphic relations among these tephra beds have not been confirmed, because they have been identified in only local outcrops. Tyo and Hng have fission-track ages of $0.53 \pm 0.19 \mathrm{Ma}$ and $0.75 \pm 0.21 \mathrm{Ma}$, respectively, measured on zircon crystals (Matsushima and Teradaira, 1990). From these fission-track ages, the Tagiri Gravel Formation is estimated to have been deposited during approximately 0.8-0.5 Ma (Matsushima, 1995).

The Nzg tephra was discovered and named at a site near Kamiakasu, Komagane City, Nagano Prefecture, N35 $42^{\prime} 43^{\prime \prime}$, E13757'35", $570 \mathrm{~m}$ a.s.l. (Locality 2, Fig. 1; Matsushima et al., 2007). Nzg is a yellowish white massive unstratified pumiceous deposite, $60 \mathrm{~cm}$ thick (Figs. 3 and 5), that consists mostly of pumice grains up to $0.5-1.0 \mathrm{~cm}$ in diameter.

The Mtj tephra was discovered in 1998 during roadworks near Minamitajima, Nakagawa Village, Nagano Prefecture; N35 $37^{\prime} 11^{\prime \prime}$, E137 ${ }^{\circ} 4^{\prime}$ 54 $^{\prime \prime}, 545 \mathrm{~m}$ a.s.l. (Locality 3, Fig. 1; Matsushima and Teradaira, 1999). Mtj is a brownish yellow massive unstratified pumiceous deposit, $40-50 \mathrm{~cm}$ thick (Figs. 3 and 6), consisting of pumice grains up to $0.3-0.5 \mathrm{~cm}$ in diameter in a sandy matrix.

\subsection{Byakubi-E tephra (Byk-E) and the Kazusa Group on the Boso Peninsula}

The Kazusa Group is composed of marine sediments and is up to $3000 \mathrm{~m}$ thick on the Boso Peninsula (Mitsunashi et al., 1979), 


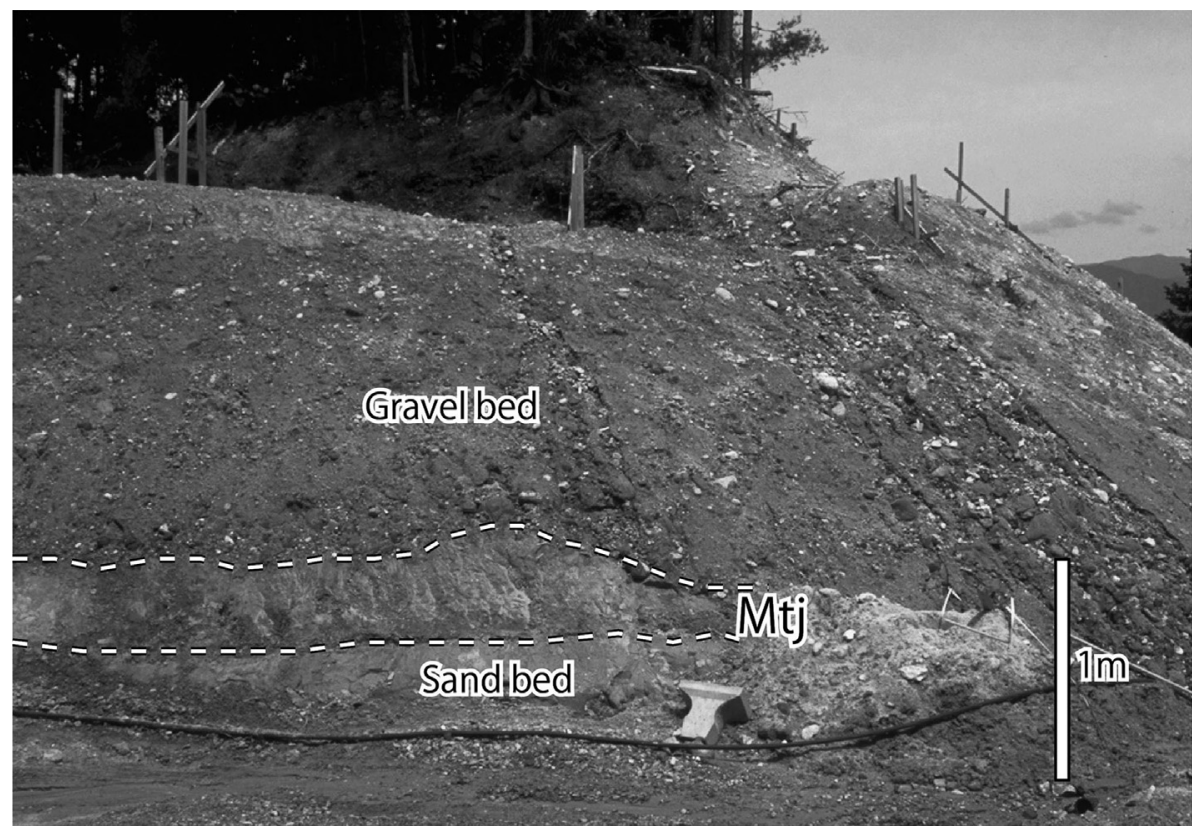

Fig. 6. Field photograph of Minamitajima tephra (Mtj) at Locality 3. Location of the section is shown in Fig. 1.

approximately $250 \mathrm{~km}$ east-southeast of Ontake volcano (Fig. 1). The Kazusa Group is one of the most important Lower and Middle Pleistocene sequences in Japan. Numerous tephra layers are intercalated with the Kazusa Group sediments (Mitsunashi et al., 1959; Machida et al., 1980; Tokuhashi and Endo, 1984; Satoguchi, 1995, 2006), and their detailed stratigraphy has been determined by using these tephra layers as key beds. On the basis of biostratigraphic (Oda, 1977; Sato and Takayama, 1988; Kanie et al., 1991; Kameo et al., 2003), magnetostratigraphic (Niitsuma, 1971, 1976), oxygen-isotope (Okada and Niitsuma, 1989; Pickering et al., 1999; Tsuji et al., 2005), and fission-track dating studies (Watanabe and Danhara, 1996; Suzuki et al., 1998), the depositional age of the
Kazusa Group has been estimated as ca. 2.4-0.4 Ma (Satoguchi, 2006). The stratigraphy of the Kazusa Group has recently been reviewed and updated (Kazaoka et al., 2015).

In the central and eastern parts of the Boso Peninsula, the Kazusa Group is divided into the Kurotaki, Katsuura, Namihana, Ohara, Kiwada, Otadai, Umegase, Kokumoto, Kakinokidai, Chonan, Kasamori, and Kongochi formations in ascending order (Tokuhashi and Endo, 1984). The Kokumoto Formation is a part of the Kazusa Group that is of primary interest here. The lowermost part of the Kokumoto Formation consists of massive sandy mud, which is overlain by thick sand beds and alternating sand-dominated layers. Its middle part consists of massive sandy mud, and its upper part is

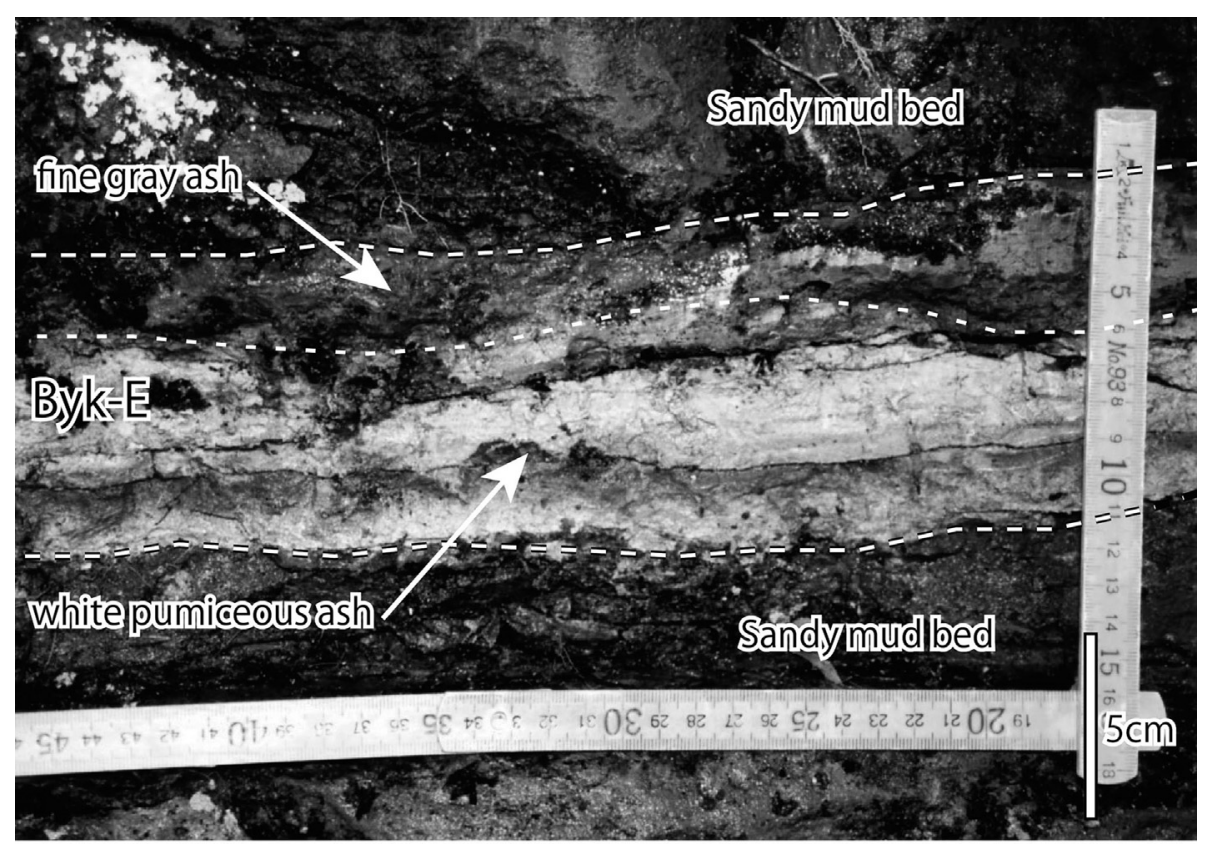

Fig. 7. Field photograph of Byk-E at Locality 4. Location of the section is shown in Fig. 1. 


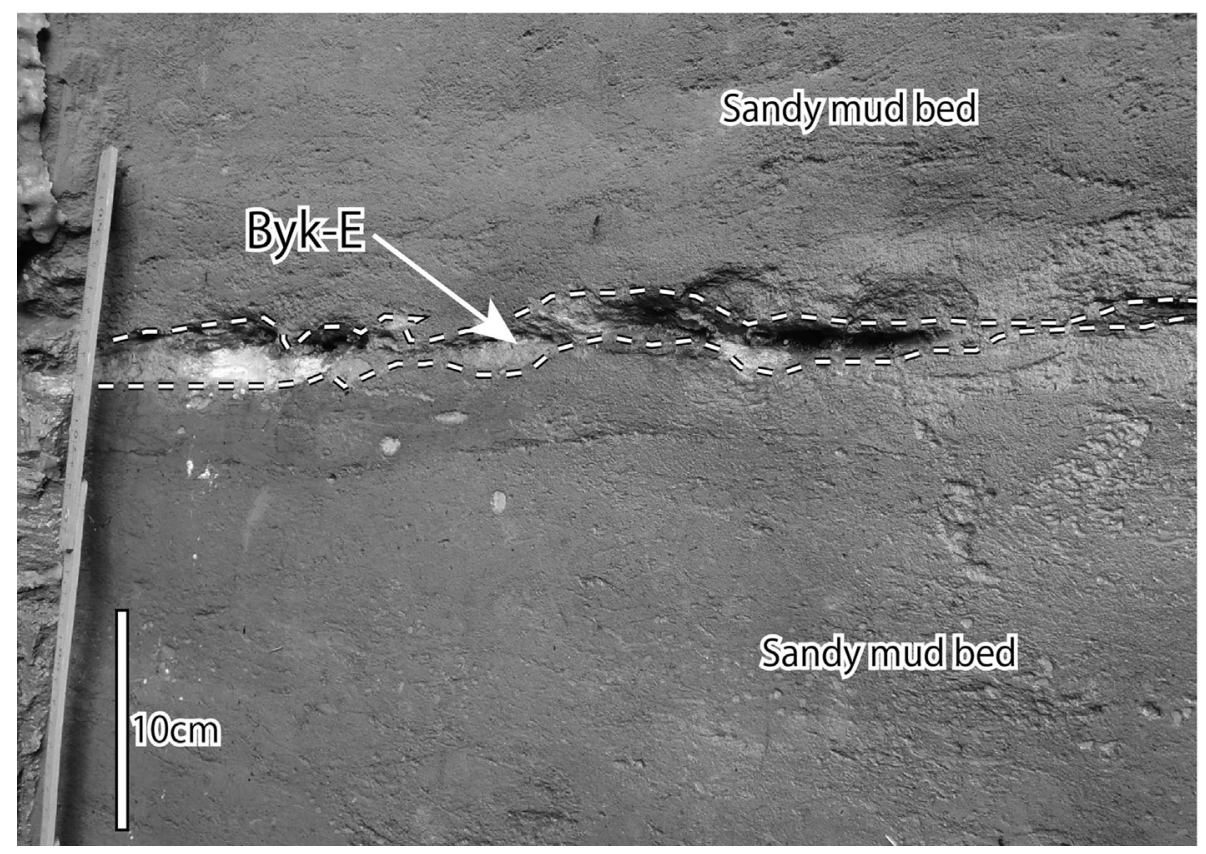

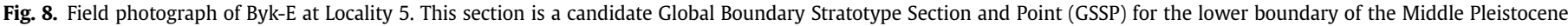
Subseries (Working Group for Quaternary Stratigraphy of Boso, 2009). Location of the section is shown in Fig. 1.

a sand-dominated alternation (Mitsunashi et al., 1959). In the middle part of the formation, more than 30 fallout tephra layers are intercalated (Workshop for Quaternary Stratigraphy of Boso, 1996). Among these tephras, Byk-E is the same as the TNTT ash layer described by Okada and Niitsuma (1989), and the Matuyama-Brunhes boundary occurs just above Byk-E (Fig. 2; Kazaoka et al., 2015). Byk-E was collected at Locality 4 on the Boso Peninsula (Fig. 1; Choja, Kimitsu City, Chiba Prefecture; N35 $16^{\prime} 21^{\prime \prime}$, E140 ${ }^{\circ} 6^{\prime} 59^{\prime \prime}, 190 \mathrm{~m}$ a.s.l.) (Takeshita et al., 2005). It is noteworthy that the Yoro River section including Locality 5 (Fig. 1; Byakubi,

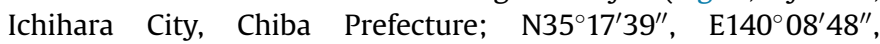
$55 \mathrm{~m}$ a.s.l.), which is the type section of the Kokumoto Formation, is a candidate GSSP for the Early-Middle Pleistocene boundary (Working Group for Quaternary Stratigraphy of Boso, 2009). In the present study, Byk-E was collected at Locality 5 for the purpose of checking whether Byk-E at Locality 4 and Byk-E at Locality 5 were the same tephra.

At Locality 4, Byk-E consists of a well-sorted white pumiceous ash bed (2-4 cm thick) and a fine gray ash bed $(2-3 \mathrm{~cm}$ thick) in ascending order (Figs. 3 and 7). Lower part of this tephra bed consists of pumice fragments with the size of fine to medium sand. At Locality 5, Byk-E consists of a well-sorted white pumiceous ash bed (1-4 cm thick) (Fig. 8). This tephra bed consists of pumice fragments with the size of fine to medium sand. At both locations, Byk-E is sandwiched between layers of dark gray sandy silt.

\section{Analytical methods}

The tephra samples collected for this study (Nzg, Mtj, and Byk-E from Locality 5) and from previously published studies (YUT4, YUT5, and Byk-E from Locality 4) were prepared as outlined in Fig. 9. The samples were washed ultrasonically after washing in a beaker. The dried residual grains were sieved to obtain the fractions from $1 / 4$ to $1 / 8 \mathrm{~mm}$ and from $1 / 8$ to $1 / 16 \mathrm{~mm}$. The $1 / 8$ to $1 / 16 \mathrm{~mm}$ fraction was used for analysis of the grain composition. Mafic minerals were separated with a neodymium magnet for determination of their mineral composition, as well as the major element composition of hornblende. The bulk grains and the mafic minerals of all samples were mounted on glass microscope slides by the Petropoxy 154 and then identified and counted under a polarizing microscope. The bulk grain and mafic mineral compositions were determined for at least 500 and 250 grains, respectively, in each

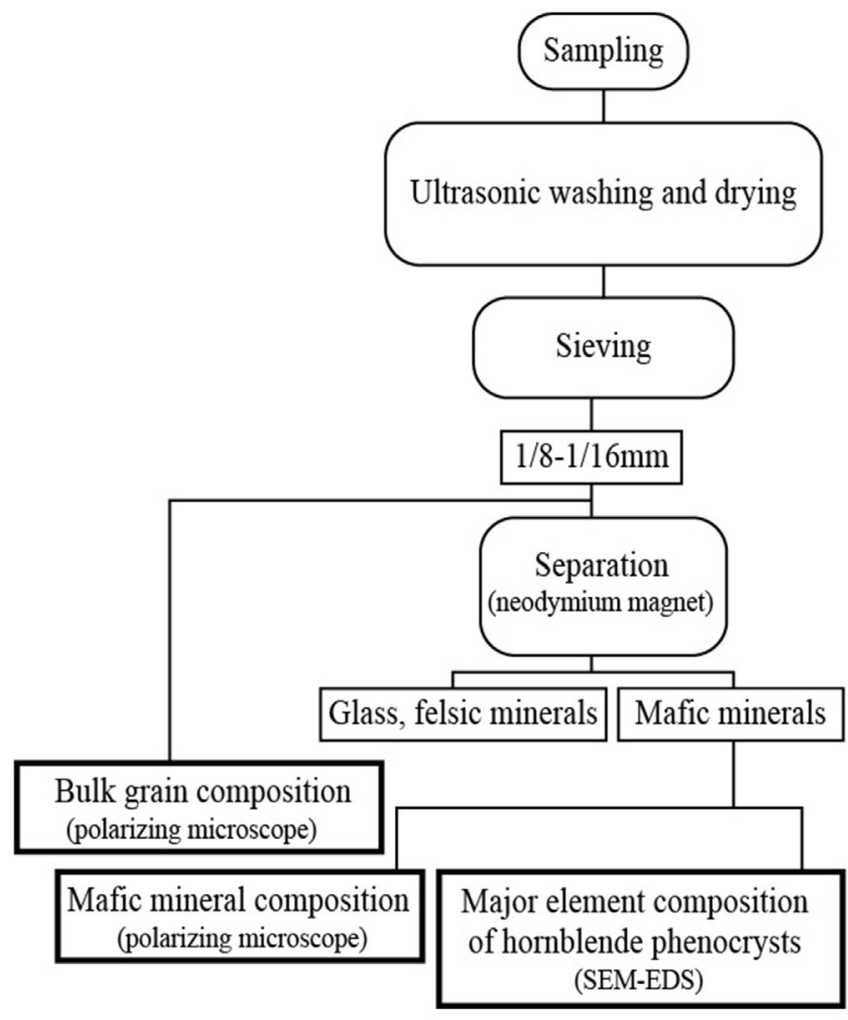

Fig. 9. Flowchart showing the sample preparation procedures for petrologic analysis and for determining the major element composition of hornblende phenocrysts. 
tephra sample. The mafic minerals identified were hornblende, orthopyroxene, clinopyroxene, garnet, opaque minerals ( $\mathrm{Fe}-\mathrm{Ti}$ oxides), zircon, and apatite. In addition, the presence of biotite was confirmed, but the number of biotite grains was not determined because they were easily fragmented during sample preparation.

Measurement of the major element composition of hornblende was carried out following Takeshita (2004) by scanning electron microscopy (JEOL, JSM5310E)-energy-dispersive X-ray spectroscopy (EDAX, Phoenix) (SEM-EDS) using an acceleration voltage of $15 \mathrm{kV}$ and a beam current of $700 \mathrm{pA}$. The apparent center of the hornblende was selected as the analytical point, and one point was measured in each grain. Phenocrysts in a tephra may become fractured during eruption, and for this reason discrimination of the rim and core was difficult. In addition, no zonal structure was observed in the hornblende phenocrysts. In each sample, 9-24 hornblende phenocrysts were analyzed.

\section{Results}

The petrographic properties of YUT4 and YUT5, Mtj, Nzg, Byk-E (Locality 4), and Byk-E (Locality 5) tephras are shown in Table 1.

\section{Discussion}

\subsection{Potential of major element composition of hornblende for tephra identification and correlation}

The correlation and identification of tephra layers are often undertaken by using glass shard characteristics (morphology, refractive index, major and trace element compositions) in addition to lithofacies, mineral composition, stratigraphic relationships, and radiometric age (Machida and Arai, 1992; Lowe, 2011). However, the volcanic glass shards of Mtj and Nzt have been altered by weathering. Thus, the major element composition of hornblende phenocrysts was used to characterise the tephras in this study.

Nine Lower and Middle Pleistocene tephra layers (Ku6E, Ku5C, Byk, Ka2.4A, B, Ch3 and 1.5, Ks18, and Ks12) in the Kazusa Group had previously been distinguished on the basis of the major element composition of their hornblende phenocrysts (Fig. 11; Takeshita et al., 2005). Moreover, it has been shown that tephras from Older Ontake volcano, Kurofuji volcano (central Japan), and Daisen volcano (southwest Japan) can be discriminated on the basis

Table 1

Petrographic properties of the YUT4, YUT5, Nzg, Mtj, and Byk-E.

\begin{tabular}{|c|c|c|c|c|c|c|c|c|c|c|c|c|c|c|c|}
\hline \multirow[t]{2}{*}{ Name of tephra } & \multirow[t]{2}{*}{ Sampling locality } & \multicolumn{4}{|c|}{ Bulk grain composition (\%) } & \multicolumn{8}{|c|}{ Mafic mineral composition (\%) } & \multirow[t]{2}{*}{ Glass morphology } & \multirow[t]{2}{*}{ Reference } \\
\hline & & G1 & P1 & R.F. & M.M. & Hb1 & Cpx & Opx & $\mathrm{Bt}$ & Opq & Ap & $\mathrm{Zr}$ & $\mathrm{Gr}$ & & \\
\hline YUT5 & Loc. 1 & 36.4 & 50.8 & 2.6 & 1.1 & 88.1 & 0.4 & 0.8 & - & 10.7 & + & + & - & $\mathrm{P}$ & 1 \\
\hline YUT4 & Loc. 1 & 34.6 & 46.9 & 4.7 & 2.8 & 70.0 & 0.8 & 0.4 & + & 24.5 & - & - & - & $\mathrm{P}$ & 1 \\
\hline Nzg & Loc. 2 & - & 88.3 & 2.5 & 9.2 & 43.8 & 0.7 & 0.4 & - & 55.1 & + & - & - & $*$ & This study \\
\hline Mtj & Loc. 3 & - & 86.6 & 4.7 & 8.7 & 39.1 & 0.8 & 0.8 & + & 59.3 & - & - & + & $*$ & This study \\
\hline Byk-E & Loc. 4 & 61.2 & 34.6 & 1.7 & 2.5 & 85.4 & + & 1.0 & - & 13.2 & 0.3 & - & - & $\mathrm{P}$ & 2 \\
\hline Byk-E & Loc. 5 & 63.6 & 31.2 & 2.1 & 3.1 & 88.3 & + & 0.7 & - & 11.0 & + & - & - & $\mathrm{P}$ & This study \\
\hline
\end{tabular}

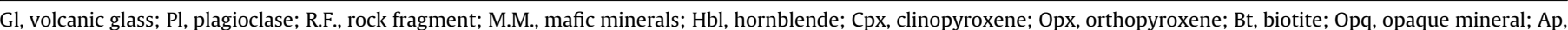
apatite; Zr, zircon; Gr, garnet; +, trace; -, absent. Glass morphology: P, pumice-type shards; *, none. References: 1, Takeshita (2004); 2, Takeshita et al. (2005).

Volcanic glass shards from YUT4 are mostly of the pumice type, but some are fiber-type shards. The hornblende content is high, and the other mafic minerals include opaque minerals and small amounts of orthopyroxene, clinopyroxene, and biotite. YUT5 is similar to YUT4 with respect to the shape of glass shards and the grain and mafic mineral compositions, but it includes apatite and zircon and lacks biotite.

The volcanic glass of Nzg has been altered by weathering. The hornblende and opaque mineral contents of Nzg are high, and other mafic minerals include small amounts of orthopyroxene and clinopyroxene. The grain and mafic mineral compositions of Mtj are similar to those of Nzg, but Mtj includes small amounts of biotite and garnet.

Byk-E (Locality 4) contains abundant volcanic glass shards. The shards are mostly of the pumice type, with some fiber-type shards. The hornblende content is high, and other mafic minerals include opaque minerals and small amounts of orthopyroxene, clinopyroxene, and apatite. Byk-E from Locality 5 is very similar to Byk-E from Locality 4 with respect to the shape of the glass shards and bulk grain and mafic mineral compositions.

The major element compositions of hornblende from YUT4 and 5, Mtj, Nzg, Byk-E (Locality 4), and Byk-E (Locality 5) are shown in Table 2 and Fig. 10. The major element composition of hornblendes from YUT5, Mtj, Nzg, and Byk-E (Locality 5) closely resemble each other. Although the major element composition of hornblende from YUT4 resembles those of the other tephras, in YUT4 Si, Al, and $\mathrm{mg}^{*}[\mathrm{Mg} /(\mathrm{Mg}+\mathrm{Fe})]$ are concentrated within a narrower range than in the other tephras. of the major element composition of hornblende (Takeshita et al., 2005; Kotaki et al., 2011). Furthermore, the major element composition of hornblende in tephra from Older Ontake volcano is different at every stage of volcanic activity (Fig. 12; Takeshita, 2004). These findings indicate that the major element composition of hornblende can be a useful tool for identification and correlation of tephras.

\subsection{Correlations of tephra layers}

\subsubsection{Correlation of Byk-E (Locality 4) and Byk-E (Locality 5)}

Byk-E (Locality 4) and Byk-E (Locality 5) were both recognized in sandy silt in the central part of the Kokumoto Formation, and the two localities are only $3.6 \mathrm{~km}$ apart (Fig. 1). Although at Locality 5, Byk-E lacks a lower part consisting of gray volcanic ash, in its thickness, grain size, grain composition, mafic mineral composition, and glass shard type, Byk-E (Locality 5 ) is very similar to Byk-E (Locality 4) (Table 1). Moreover, the major element compositional ranges of hornblende from Byk-E (Locality 4) are very similar to those of Byk-E (Locality 5) (Table 2, Fig. 10). From these results, we infer that Byk-E (Locality 4) and Byk-E (Locality 5) are certainly the same tephra.

\subsubsection{Correlation of Byk-E (Boso), Mtj, Nzg (Ina), and YUT5 (Older Ontake volcano)}

Byk-E was previously correlated with YUT4 or YUT5 from the Older Ontake volcano on the basis of their lithofacies, glass shard type, grain composition, mafic mineral composition, major 


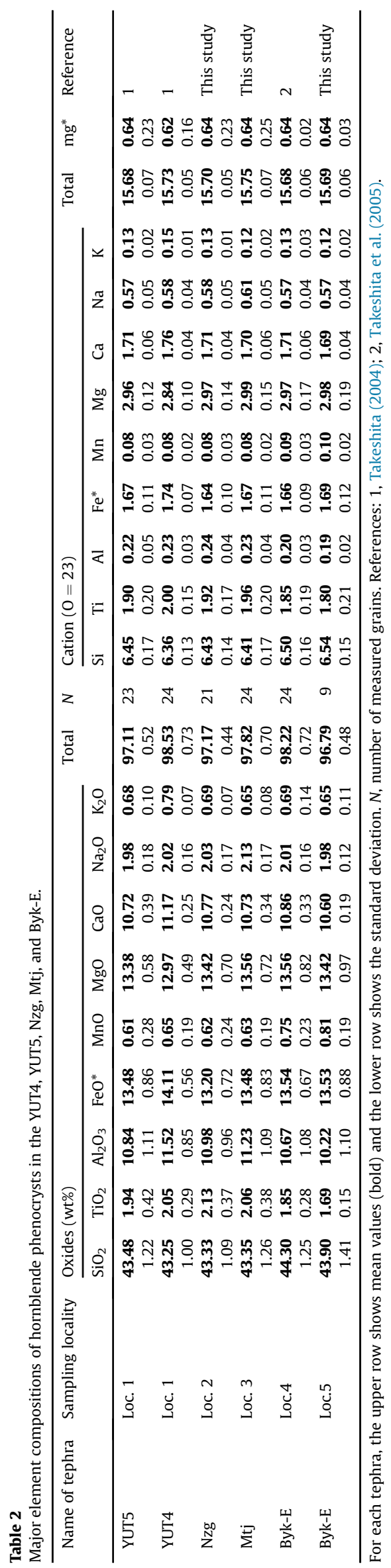

element composition of hornblende, $\mathrm{K}-\mathrm{Ar}$ ages of lava, and stratigraphic relationships with the Matuyama-Brunhes boundary (Takeshita et al., 2005). Mtj and Nzg are both hornblende-rich pumiceous deposits, and their mafic mineral compositions are similar to those of Byk-E, YUT4, and YUT5. Measurements of the major element compositions of hornblende showed that, unlike in YUT4, in YUT5, Byk-E, Mtj, and Nzg, the range of variation in Si and mg* was large; moreover, the variation range of $\mathrm{Al}$ was lower in YUT4 than in these other tephras (Fig. 10). This result suggests that Byk-E, Mtj, and Nzg are correlated with YUT5 but not with YUT4 (Fig. 2), and that the composition ranges of $\mathrm{Si}, \mathrm{Al}$, and $\mathrm{mg}^{*}$ in hornblende phenocrysts can be used to distinguish YUT5 from YUT4.

Among the tephra layers that are the focus of this study, only Mtj includes small amount of garnet and biotite grains, which tend to be rounded and fragmental. Both garnet and biotite are found in the granitic and metamorphic rocks of the Kiso Mountains (Murayama and Katada, 1957) and a large amount of the gravel in the Tagiri Gravel Formation is derived from those rocks. We suggest, therefore, that fragments of garnet and biotite probably became mixed in with the Mtj tephra by resedimentation, because Mtj is massive unstratified pumiceous deposit consisting of pumice grains and sandy matrix.

Next, we investigated correlations among Byk-E, Mtj, Nzg, and YUT5 from the viewpoint of chronology and volcanology. The Matuyama-Brunhes boundary occurs just above Byk-E at Chiba section (Kazaoka et al., 2015), and chronologically it is positioned at the boundary between marine oxygen-isotope substages (MIS) 19.3 and 19.2 (Hyodo et al., 2006; Hyodo, 2014). The Ku1 tephra, which occurs about $50 \mathrm{~m}$ above Byk-E, correlates with the widespread Hakkoda-Kokumoto tephra (Hkd-Ku: Suzuki et al., 2005), which has been correlated in turn with the Imakuma I tephra, Osaka Group (Itihara et al., 1975), and the Hakkoda first-stage pyroclastic flow deposits in northernmost Honshu (Muraoka and Takakura, 1988). Ku1 (Hkd-Ku) was erupted around $0.76 \mathrm{Ma}$, between MIS 19.1 and MIS 18.4 (Suzuki et al., 2005). Consequently, we can estimate the age of Byk-E as ca. $0.773 \mathrm{Ma}$ (Fig. 2). On the other hand, Mtj and Nzg are intercalated in the Tagiri Gravel Formation, the estimated depositional age of which is approximately $0.8-0.5 \mathrm{Ma}$, based on its stratigraphic relation with On-Pm1 (0.1 Ma) and fission-track ages from Tyo (0.53 $\pm 0.19 \mathrm{Ma})$ and Hng $(0.75 \pm 0.21 \mathrm{Ma})$ (Matsushima, 1995). Therefore, the correlation of Mtj and Nzg with Byk-E (YUT5) is congruent with the chronological framework.

Thickness of the Mtj and Nzg in the Ina Basin is almost same as that of YUT5 at the foot of Ontake volcano. However, those of Mtj and YUT5 probably not original thickness, because YUT5 overlies the slope landform at Locality 1 (Fig. 4), and Mtj is probably reworked pumice-fall deposits. Therefore, we confirm this correlation depending on the size of pumice grains and lithofacies of these tephra beds. YUT5 is considered a Plinian pumice-fall deposit because it consists of sorted pumice clasts up to $1.0-2.0 \mathrm{~cm}$ in diameter (Takeshita, 2004). Byk-E is thought to be distal ashfall deposits associated with a Plinian eruption because it includes pumice fragments the size of fine to medium sand (Takeshita et al., 2005). Mtj and Nzg in the Ina Basin are regarded as, possibly reworked, Plinian pumice-fall deposits because they consist of pumice grains up to $0.3-1.0 \mathrm{~cm}$ in diameter. The pumice size of Mtj and Nzg is thus smaller than that of YUT5 and larger than that of Byk-E, consistent with the location of the Ina Basin between Ontake volcano and the Boso Peninsula (Table 1). Accordingly, it is reasonable to infer that YUT5, Mtj, Nzt, and Byk-E are volcanic products from the same eruption.

YUT5, Mtj, and Nzg, which are correlated with Byk-E, cannot be called volcanic ash, because they consist of pumice clasts coarser 

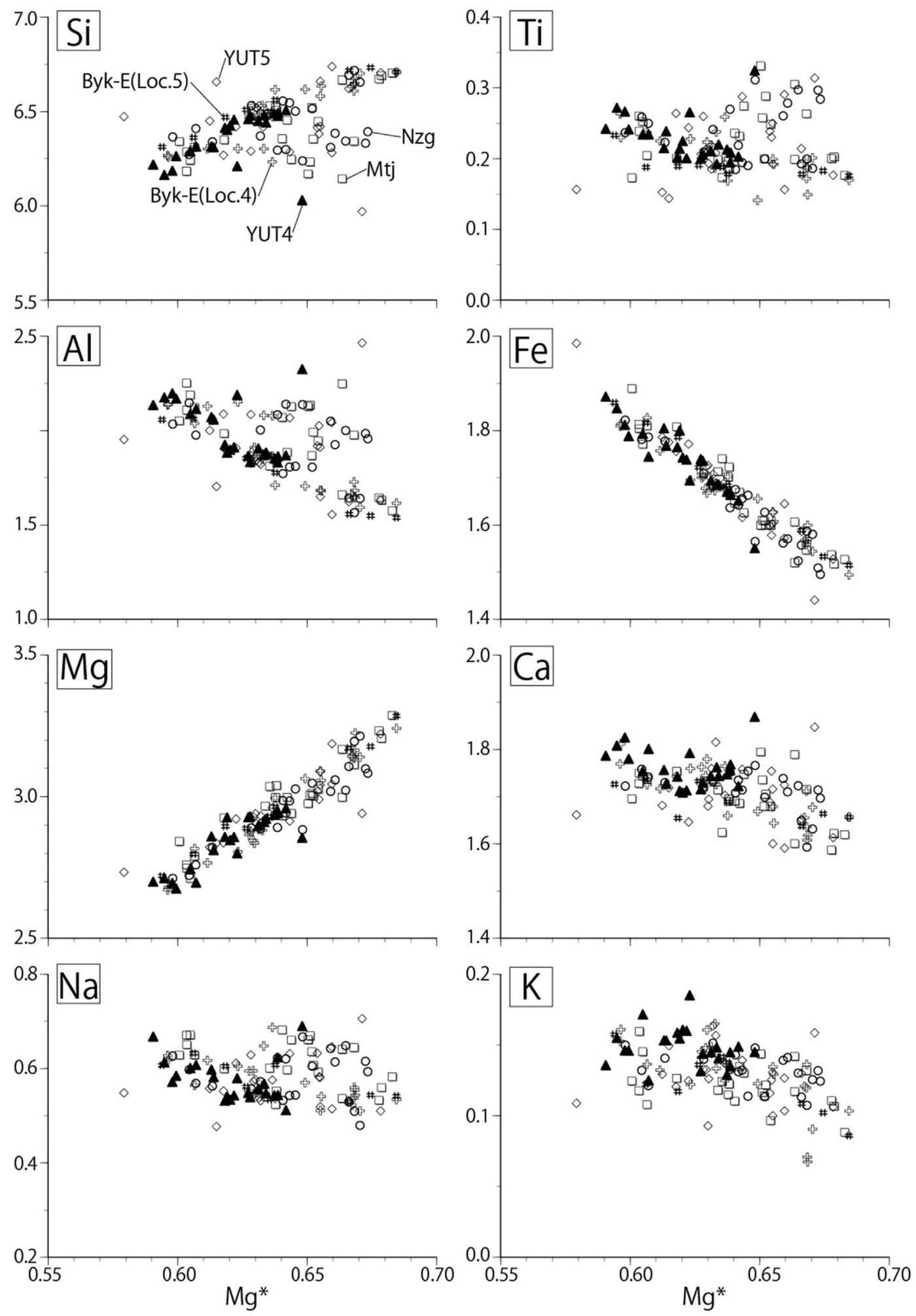

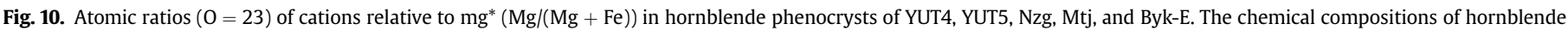
from YUT4 and YUT5 are after Takeshita (2004). Those from Byk-E (Locality 4) are after Takeshita et al. (2005). 

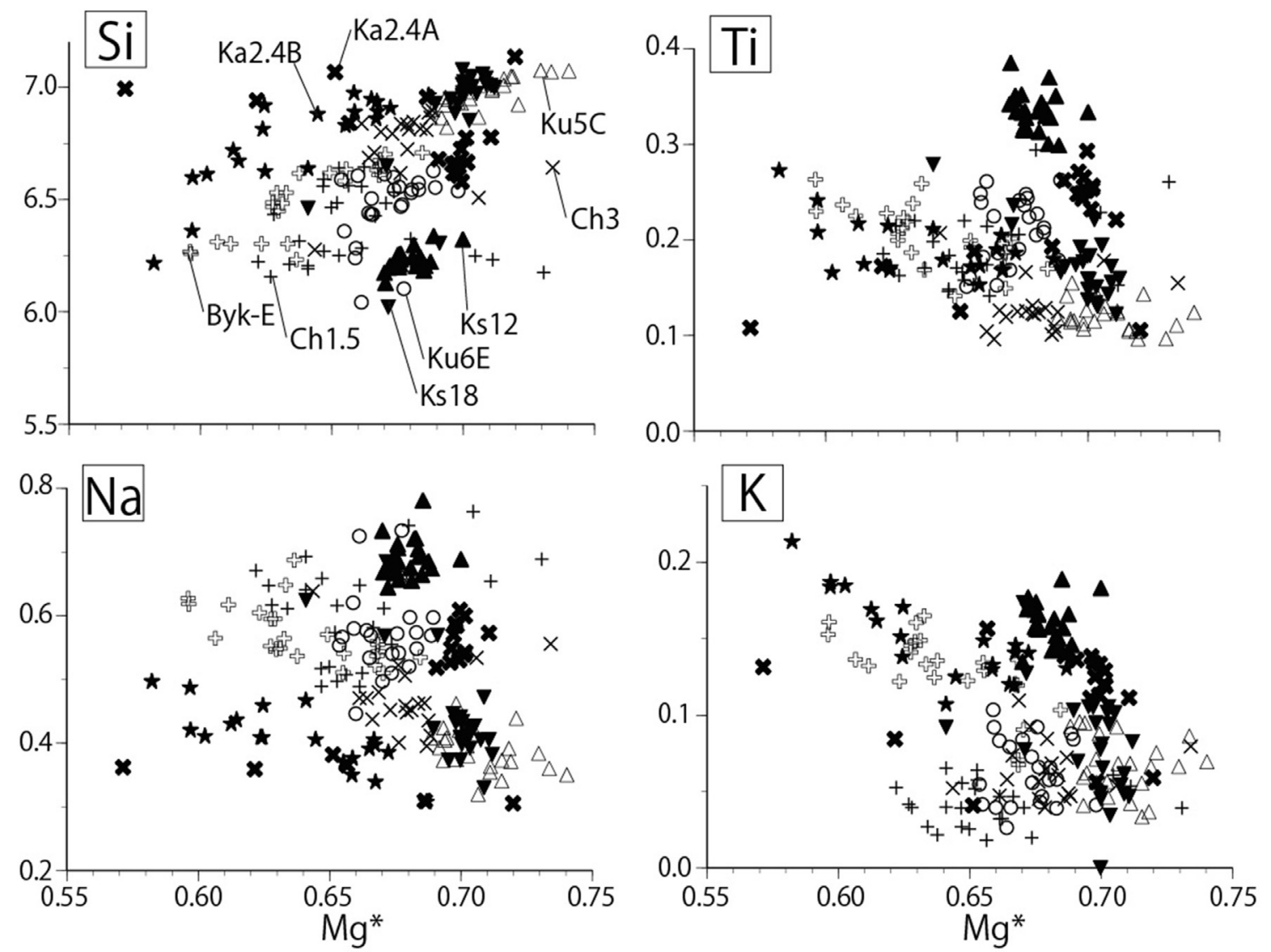

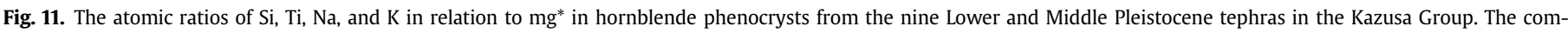

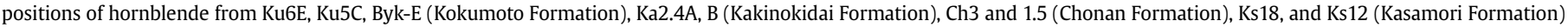
are after Takeshita et al. (2005).

than $2 \mathrm{~mm}$. Thus, we propose to call the series of tephras correlated with Byk-E the Ontake-Byakubi Tephra Bed (On-Byk Tephra), following the naming convention in which the tephra name consists of the names of the source volcano and the type location (Machida and Arai, 1992).

\subsection{Significance of the Ontake-Byakubi tephra}

In Japan, most volcanic glass shards included in Middle Pleistocene tephra beds are sandwiched within nonmarine sediments, such as fluvial or tephric soil (eolian) deposits, and have been altered by weathering (Takeshita et al., 2007; Suzuki, 2008; Kotaki et al., 2011). In this study, strongly weathered tephra beds such as Mtj and Nzg have been correlated with the On-Byk Tephra by using the major element composition of hornblende as a means of tephra identification. Furthermore, we distinguished YUT5 from YUT4 and showed that Byk-E is correlated with YUT5 by using the major element composition of hornblende determined for Mtj and Nzg. These results clearly show that On-Byk Tephra is an important marker tephra that can provide a datum plane that approximates the Lower-Middle Pleistocene boundary.

Deposition of the Tagiri Gravel Formation began before about $0.773 \mathrm{Ma}$, because On-Byk Tephra (Mtj and Nzg) is intercalated within this formation (Fig. 2). It follows, therefore, the Kiso Mountains had uplifted sufficiently to provide gravel to the Ina basin by about $0.78 \mathrm{Ma}$. Thus, as a high-precision datum plane, OnByk Tephra can contribute to the reconstruction of the geomorphologic and geologic evolution of the Chubu district, central
Japan, in nonmarine sediments that otherwise lack chronological indices.

In Japan, most late Quaternary tephras are distributed to the east of their source volcanoes, because the plumes were transported by the prevailing westerlies (Machida and Arai, 2003). Some Middle to Upper Pleistocene tephras such as the Aso-4 and Ata-Torihama (Machida, 1999) tephras have been identified in the northwest Pacific Ocean (Suganuma et al., 2006; Aoki, 2008; Aoki et al., 2008). Therefore, it is possible that On-Byk, which has a thickness of $1-7 \mathrm{~cm}$ on the Boso Peninsula, also occurs in the northwest Pacific Ocean. Thus, On-Byk Tephra, because it approximates the Middle Pleistocene boundary, may contribute to the development of a high-precision chronology close to the Matuyama-Brunhes transition.

\section{Conclusion}

Petrographic features including bulk grain and mafic mineral compositions and the major element composition of hornblende from tephras Mtj and Nzg in the Ina basin have been described and compared with previously published data for tephras YUT4, YUT5, and Byk-E.

We are able to distinguish YUT5 from YUT4 and to correlate BykE, Mtj, and Nzg with YUT5 on the basis of the major element composition of hornblende.

We propose that the series of tephras correlated with Byk-E be called the Ontake-Byakubi Tephra Bed (On-Byk Tephra). On-Byk is an important marker tephra because it provides a datum plane that closely approximates the Lower-Middle Pleistocene boundary. 

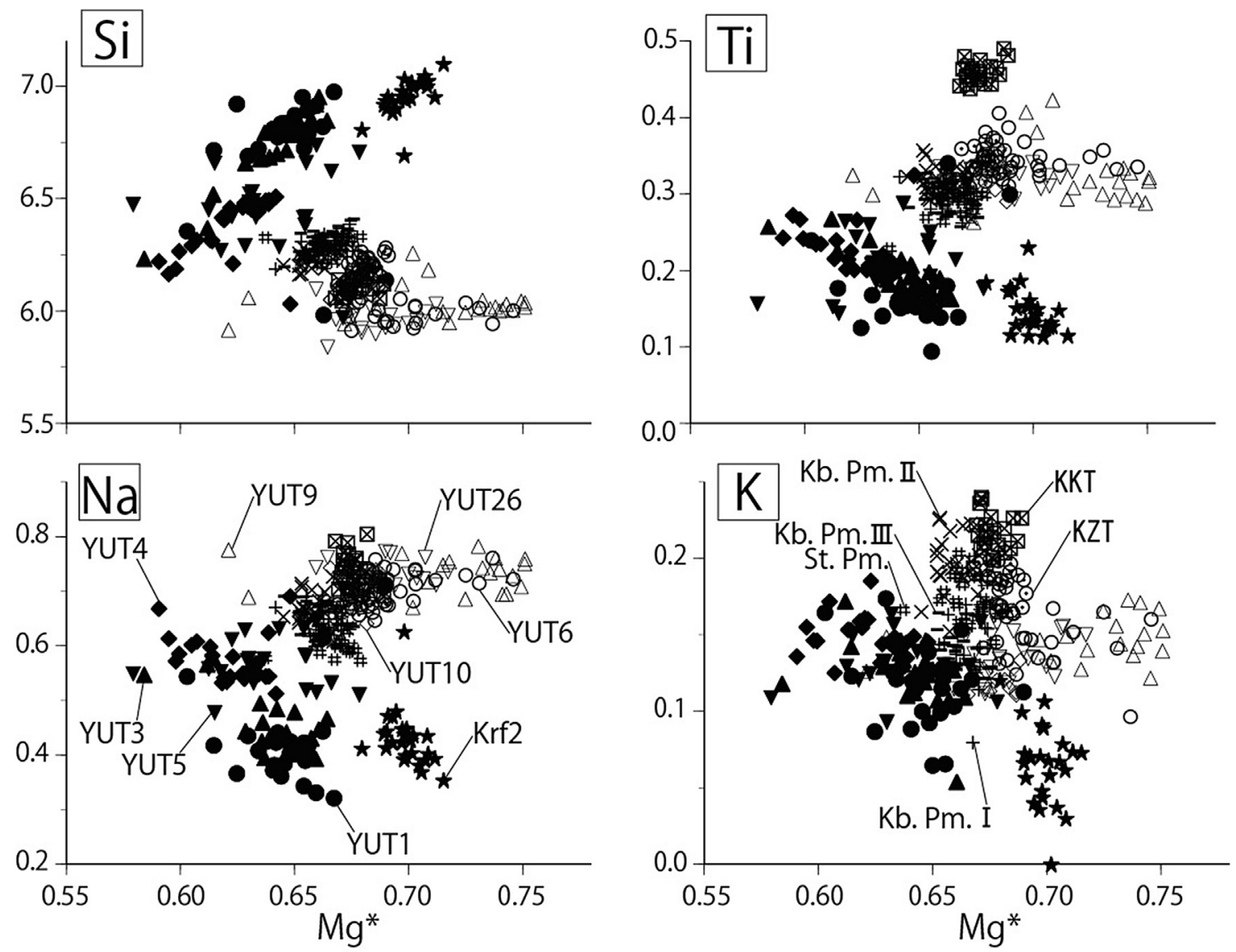

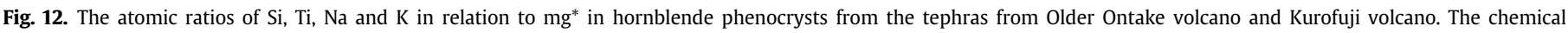

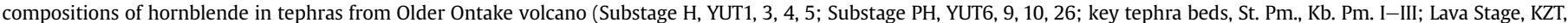
KKT) are after Takeshita (2004), and data from Kurofuji volcano (Krf2) are after Takeshita et al. (2005).

The present study also shows that the major element composition of hornblende phenocrysts can a useful tool for correlating strongly weathered tephra layers in which all the volcanic glass shards have been altered.

\section{Acknowledgements}

We thank Prof. Yasuyuki Miyake, Prof. Kuniaki Makino and Mr. Tatsuro Tsugane, Shinshu University for providing many helpful suggestions during the EDS analyses.

\section{References}

Aoki, K., 2008. Revised age and distribution of ca. 87ka Aso-4 tephra based on new evidence from the northwest Pacific Ocean. Quaternary International 178, $100-118$.

Aoki, K., Irino, T., Oba, T., 2008. Late Late Pleistocene tephrostratigraphy of the sediment core MD01-2421 collected off the Kashima coast, Japan. The Quaternary Research (Daiyonki Kenkyu) 47, 391-407 (in Japanese with English abstract).

Channell, J.E.T., Hodell, D.A., Singer, B.S., Xuan, C., 2010. Reconciling astrochronological 661 and $40 \mathrm{Ar} / 39 \mathrm{Ar}$ ages for the Matuyama-Brunhes boundary and late Matuyama Chron. Geochemistry, Geophysics, Geosystems 11, Q0AA12. http:/ dx.doi.org/10.1029/2010GC003203.

Head, M.J., Pillans, B., Farquhar, S., 2008. The Early-Middle Pleistocene Transition: characterization and proposed guide for the defining boundary. Episodes 31, $255-259$.

Hyodo, M., 2014. Reversal of Earth's magnetic field -detailed magnetoclimatostratigraphy and geomagnetic influence on climate. The Quaternary Research (Daiyonki Kenkyu) 53,1-20 (in Japanese with English abstract).

Hyodo, M., Biswas, D.K., Noda, T., Tomioka, N., Mishima, T., Itota, C., Sato, H., 2006. Millennial to submillennial-scale features of the Matuyama-Brunhes geomagnetic polarity transition from Osaka Bay, southwestern Japan. Journal Geophysical Research 111, B02103.
Itihara, M., Yoshikawa, S., Inoue, K., Hayashi, T., Tateishi, M., Nakajima, K., 1975. Stratigraphy of the Plio-Pleistocene Osaka Group in Sennan-Senpoku area, South of Osaka, Japan - a standard stratigraphy of the Osaka Group. Journal of Geosciences, Osaka City University 19, 1-29.

Kameo, K., Saito, K., Kotake, N., Okada, M., 2003. Late Pliocene sea surface environments in the Pacific side of central Japan based on calcareous nannofossils from the lower part of the Chikura Group, southernmost part of the Boso Peninsula. Journal of Geological Society of Japan 109, 478-488 (in Japanese with English abstract).

Kanie, Y., Okada, H., Sasahara, Y., Tanaka, H., 1991. Calcareous nannoplankton age and correlation of the Neogene Miura Group between the Miura and Boso Peninsulas, southern-central Japan. Journal of Geological Society of Japan 97, 135-155 (in Japanese with English abstract).

Kazaoka, O., Suganuma, Y., Okada, M., Kameo, K., Head, M.J., Yoshida, T., Kameyama, S., Nirei, H., Aida, N., Kumai, H., 2015. Stratigraphy of the Kazusa Group, Boso Peninsula, Central Japan: an expanded and highly-resolved marine sedimentary record from the Lower and Middle Pleistocene. Quaternary International (in press). http://dx.doi.org/10.1016/j.quaint.2015.02.065.

Kimura, J., 1993. The Late Pleistocene Ontake volcano: reappraisal of volcanic activity using volcanostratigraphy combined with tephrostratigraphy. Earth Science (Chikyu Kagaku) 47, 301-321 (in Japanese with English abstract).

Kioka, H., Furuyama, K., Miyake, Y., Sakai, J., Nagao, K., Ikemoto, M., Noiri, H., Oda, K. 1998. K-Ar chronology of the Middle Pleistocene lavas at Ontake volcano, central Japan. Earth Science (Chikyu Kagaku) 52, 464-474.

Kobayashi, K Shimizu, H., Kitazawa, K., Kobayashi, T, 1967. The pumice-fall deposit "Pm-I" supplied from Ontake volcano-study of the pumice-fall deposit "Pm-I" supplied from Ontake volcano No. 1. Journal of Geological Society of Japan 73, 291-308 (in Japanese with English abstract).

Kotaki, A., Katoh, S., Kitani, K., 2011. Correlation of Middle Pleistocene crystal-rich tephra layers from Daisen Volcano, southwest Japan, based on the chemical composition and refractive index of mafic minerals. Quaternary International 246, 105-117.

Lowe, D.J., 2011. Tephrochronology and its application: a review. Quaternary Geochronology 6, 107-153.

Machida, H., 1999. The stratigraphy, chronology and distribution of distal markertephras in and around Japan. Global and Planetary Change 21, 71-94.

Machida, H., Arai, F., 1992. Atlas of Tephra in and Around Japan. University of Tokyo Press, Tokyo, p. 276 (in Japanese). 
Machida, H., Arai, F., 2003. Atlas of Tephra in and Around Japan (Revised Edition). University of Tokyo Press, Tokyo, p. 336 (in Japanese).

Machida, H., Arai, F., Sugihara, S., 1980. Tephrochronological study on the middle Pleistocene deposits in the Kanto and Kinki districts, Japan. The Quaternary Research (Daiyonki Kenkyu) 19, 233-261 (in Japanese with English abstract).

Matsumoto Basin Collaborative Research Group, 2002. Geology of the Older Ontake Volcano, Central Japan. Earth Science (Chikyu Kagaku) 56, 65-85 (in Japanese with English abstract).

Matsushima, N., 1995. Morphogenetic History of the Ina Basin. Research Report of the Iida City Museum 3, p. 145 (in Japanese).

Matsushima, N., Teradaira, H., 1990. Topography and geology of Iijima town. Iijima town magazine (Iijima chou-shi) 11-136 (in Japanese).

Matsushima, N., Teradaira, H., 1999. Geomorphic chronology in relation to the climatic change and the earth movement in Ina tectonic basin, central Japan. Bulletin of the Iida City Museum 9, 171-198 (in Japanese).

Matsushima, N., Teradaira, H., Hara, H., Shimodaira, M., Kitazawa, N., 2007. Topography and geology of Komagane city - the area and environment, the history of the land. Komagane City Magazine (Komagane shi-shi) 7-204 (in Japanese).

Mitsunashi, T., Yasukuni, N., Shinada, Y., 1959. Stratigraphical section of the Kazusa Group along the shores of rivers Yoro and Obitsu. Bulletin of the Geological Survey of Japan 10, 83-98 (in Japanese with English abstract).

Mitsunashi, T., Kikuchi, T., Suzuki, Y., Hirayama, J., Nakajima, T., Oka, S., Kodama, K., Horiguchi, M., Katsurajima, S., Miyashita, M., Yazaki, K., Kageyama, K., 1979. Explanatory Text of the Geological Map of Tokyo Bay and Adjacent Areas, Scale 1:100 000. Geological Survey of Japan, Tsukuba, p. 67 (in Japanese with English abstract).

Muraoka, H., Takakura, T., 1988. Explanatory Text of the Geological Map of Hakkoda Geothermal Area, Scale 1:100 000. Geological Survey of Japan, Tsukuba, p. 27 (in Japanese with English abstract).

Murayama, M., Katada, M., 1957. Geology of the Akaho District, with Geological Sheet Map at 1:50 000. Geological Survey of Japan, Tsukuba, p. 45 (in Japanese with English abstract)

Niitsuma, N., 1971. Detailed Study of the Sediments Recording the MatuyamaBrunhes Geomagnetic Reversal. In: Science Report of the Tohoku University Second Series (Geology) 43, pp. 1-39.

Niitsuma, N., 1976. Magnetic stratigraphy in the Boso Peninsula. Journal of Geological Society of Japan 82, 163-181 (in Japanese with English abstract).

Oda, M., 1977. Planktonic Foraminifera Biostratigraphy of the Late Cenozoic Sedimentary Sequence, Central Honshu, Japan. In: Science Report Tohoku University, 2nd Series (Geology) 48, pp. 1-72.

Oikawa, T., 2014. Diversity of phreatic erupution and Ontake 2014 Eruption. In: The Volcanological Society of Japan 2014 Fall Meeting "Supplement: Emergency Academic Session", Programme and Abstract, U1 (in Japanese).

Okada, M., Niitsuma, N., 1989. Detailed paleomagnetic records during the BrunhesMatuyama geomagnetic reversal, and a direct determination of depth lag magnetisation in marine sediments. Physics of the Earth and Planetary Interiors 56, 133-150.

Pickerring, K.T., Souter, C., Oba, T., Taira, A., Schaaf, M., Platzman, E., 1999. Glacio-eustatic control on deep-marine clastic forearc sedimentation, Pliocene-mid-Pleistocene (ca 1180-600 ka) Kazusa Group, SE Japan. Journal of the Geological Society of London 156, 125-136.

Sato, T., Takayama, T., 1988. Calcareous nannofossil zones of the Quaternary. Memoirs of the Geological Society of Japan 30, 205-217 (in Japanese with English abstract).

Satoguchi, Y., 1995. Tephrostratigraphy in the lower to middle Kazusa Group in the Boso Peninsula, Japan. Journal of Geological Society of Japan 101, 767-782 (in Japanese with English abstract).

Satoguchi, Y., 1996. Tephrostratigraphy of Quaternary System in the Boso Peninsula, Japan. In: Proceedings on the Research of Stratotype for the Lower-Middle
Pleistocene Boundary, Inter Research Group for the Lower-Middle, MiddleUpper Pleistocene Boundary. Japan Association for Quaternary Research, pp. 24-35.

Satoguchi, Y., 2006. Wide area tephrostratigraphy based on stratigraphy of PlioPleistocene formations in Boso Peninsula, Japan. Chikyu Monthly 28, 49-55 (in Japanese).

Satoguchi, Y., Nagahashi, Y., 2012. Tephrostratigraphy of the Pliocene to Middle Pleistocene Series in Honshu and Kyushu Islands, Japan. Island Arc 21, 149-169.

Suganuma, Y., Aoki, K., Kanamatsu, T., Yamazaki, T., 2006. Tephrostratigraphy of deep-sea sediments in the Northwestern Pacific and its implications for the chronology of the Past 300 kyr. The Quaternary Research (Daiyonki Kenkyu) 45, 435-450 (in Japanese with English abstract).

Suzuki, T., 2008. Analysis of titanomagnetite within weathered middle Pleistocene KMT tephra and its application for fluvial terrace chronology, Kanto Plain, central Japan. Quaternary International 178, 119-127.

Suzuki, T., Fujiwara, O., Danhara, T., 1998. Fission track ages of Several Quaternary Tephras in Kanto and Chubu Regions, Central Japan. Journal of Geography 107, 348-367 (in Japanese with English abstract).

Suzuki, T., Eden, D., Danhara, T., Fujiwara, O., 2005. Correlation of the HakkodaKokumoto Tephra, a widespread Middle Pleistocene tephra erupted from the Hakkoda Caldera, northeast Japan. Island Arc 14, 666-678.

Takeshita, Y., 2004. Volcanic history of the Middle Pleistocene Older Ontake Volcano, Central Japan: inferences from tephrostratigraphy and petrography. Journal of the Geological Society of Japan 110, 158-174 (in Japanese with English abstract).

Takeshita, Y., Miyake, Y., Sakai, J., 2005. Correlation of the tephra beds in the Middle Pleistocene Older Ontake Volcano with those in the Kazusa Group in Boso Peninsula, central Japan. Journal of the Geological Society of Japan 111, 417-433 (in Japanese with English abstract).

Takeshita, Y., Miyake, Y., Sakai, J., 2007. Correlation of the Middle Pleistocene tephra beds from the Older Ontake Volcano with those in the southern part of Matsumoto basin, central Japan. The Quaternary Research (Daiyonki Kenkyu) 46, 131-146 (in Japanese with English abstract).

Tokuhashi, S., Endo, H., 1984. Geology of the Anesaki District, with Geological Sheet Map at 1:50 000. Geological Survey of Japan, Tsukuba, p. 136 (in Japanese with English abstract).

Tsuji, T., Miyata, Y., Okada, M., Mita, I., Nakagawa, H., Sato, Y., Nakamizu, M., 2005. High resolution chronology of the lower Pleistocene Otadai and Umegase Formations of the Kazusa Group, Boso Peninsula, central Japan - chronostratigraphy of the JNOC TR-3 cores based of oxygen isotope, magnetostratigraphy and calcareous nannofossil. Journal of Geological Society of Japan 111, 1-20 (in Japanese with English abstract).

Watanabe, M., Danhara, T., 1996. Fission track ages of volcanic ash layers of the Kazusa Group in the Boso Peninsula, central Japan. Journal of the Geological Society of Japan 102, 545-556 (in Japanese with English abstract).

Working Group for Quaternary Stratigraphy of Boso, 2009. Stratigraphy and Geological Science of the Pliocene-Pleistocene Kazusa Group in the Boso Peninsula on the Pacific Ocean, Central Japan. In: Digital Book: Progress in Quaternary Research in Japan. The Association for Quaternary Research. CDROM and Booklet, 30 pp. (in Japanese).

Workshop for Quaternary Stratigraphy of Boso, 1996. Stratigraphy of Quaternary Sediments in the Boso Peninsula on the Pacific Ocean, Central Japan. In: Proceedings on the Research of Stratotype for the Lower-Middle Pleistocene Boundary, Inter Research Group for the Lower-Middle, Middle-Upper Pleistocene Boundary. Japan Association for Quaternary Research, pp. 13-23.

Yamada, N., Kobayashi, T., 1988. Geology of the Ontakesan District with Geological Sheet Map at 1: 50,000. Geological Survey of Japan, Tsukuba, p. 136 (in Japanese with English abstract). 